\title{
PEMBERDAYAAN PEREMPUAN PEDESAAN MELALUI PELATIHAN PENGELOLAAN SAMPAH RUMAH TANGGA
}

\author{
Nurin Rochayati ${ }^{1 *}$, Agung Pramunarti ${ }^{2}$, Hj.Mas'ad ${ }^{3}$, Suryani $^{4}$
}

\begin{abstract}
${ }^{1 *}$ Program Studi Pendidikan Geografi, Fakultas Keguruan dan Ilmu Pendidikan, Universitas Muhammadiyah Mataram 2Program Studi Pendidikan Geografi, Fakultas Keguruan dan IImu Pendidikan, Universitas Muhammadiyah Mataram ${ }^{3}$ Program Studi Pendidikan Geografi, Fakultas Keguruan dan IImu Pendidikan, Universitas Muhammadiyah Mataram ${ }^{4}$ Program Studi Pendidikan Geografi, Fakultas Keguruan dan IImu Pendidikan, Universitas Muhammadiyah Mataram

${ }^{*}$ Corresponding author :

E-mail: nurin.geo99@gmail.com
\end{abstract}

Diterima 10 April 2018, Disetujui 13 April 2018

\begin{abstract}
ABSTRAK
Pemberdayaan merupakan suatu usaha kegiatan untuk meningkatkan dan mengembangkan potensi yang ada pada individu-masyarakat sehingga dapat meningkatkan harkat dan martabat manusia secara maksimal. Pemberdayaan perempuan sebagai upaya untuk mengembangkan potensi wanita dalam kehidupan bermasyarakat. Salah satu contoh dengan mengadakan pelatihan pengolahan sampah rumah tangga. Tujuan diadakan kegiatan pelatihan ini untuk meningkatkan skill Perempuan pedesaan tentang manfaat daur ulang sampah rumah tangga (sampah plastik), untuk mengurangi sifat konsumtif sehingga dapat minimalisir sampah rumah tangga. Pengabdian masyarakat ini dilaksanakan di desa Langko kecamatan Lingsar Kabupaten Lombok Barat Nusa Tenggara Barat. Kegiatan ini diikuti oleh ibu rumah tangga, remaja putri yang berjumlah 21 orang (dari 7 dusun). Meskipun kegiatan ini berlangsung selama 2 hari (yang singkat) perempuan desa Langko sangat antusias dan termotivasi dalam mengikuti kegiatan tersebut. Pelatihan pengolahan sampah ini difokuskan untuk mengolah sampah plastik dijadikan asesoris, hiasan dinding,pot bunga dll.
\end{abstract}

Kata Kunci: Pelatihan, Pengelolaan, Sampah Rumah Tangga

\begin{abstract}
Empowerment is an activity to improve and develop the individual-community potency so as to increase the dignity of human beings maximally. Empowerment of woman as an effort to develop woman potency in social life. Provide the training on household waste processing is an example of woman's empowerment. The objectives of this training were to improve skill of village woman about benefits of household waste recycling (plastic waste) and to minimize household waste caused by consumptive nature. This training held in Langko Village, Lingsar Sub-District, West Lombok Regency and was followed by 21 participants consisting of housewives and teenager (from 7 hamlets). This training held two days with the great enthusiasm of Langko's woman village and motivated them to attend the training. The training has focused to process plastic waste into an accessories, wall decorations, flower vase, etc.
\end{abstract}

Key Words: Training, Installation of Household Electric Lights, EWB Media

\section{PENDAHULUAN}

Proses pemberdayaan dalam konteks aktualisasi diri berkaitan dengan upaya untuk meningkatkan kemampuan individu dengan menggali segala potensi yang dimiliki oleh individu tersebut baik menurut kemampuan keahlian (skill) ataupun pengetahuan (knowledge). Pada intinya pemberdayaan adalah membantu klien untuk memperoleh daya untuk mengambil keputusan dan menentukan tindakan yang akan dilakukan terkait dengan diri mereka termasuk mengurangi hambatan pribadi dan sosial. Hal ini dilakukan untuk meningkatkan kemampuan dan rasa percaya diri untuk menggunakan daya yang dimiliki antara lain dengan transfer daya dari lingkunganya. Perlu dipikirkan siapa yang sesungguhnya menjadi sasaran pemberdayaan. Pandangan pemberdayaan sebagai suatu bagian dari masyarakat miskin dengan tidak harus menghilangkan ketimpangan struktural lebih dahulu. Masyarakat miskin sesungguhnya juga memiliki daya untuk membangun. Perempuan memiliki peranan penting dalam proses produksi. 
Menurut FAO, jumlah perempuan yang terlibat di sektor pertanian setiap tahunnya mengalami peningkatan. Peningkatan yang terjadi mencapai empat kali lipat dari tahun 1960 sebanyak 7,43 juta menjadi 20,82 juta orang pada tahun 2000. Perbandingan jumlah tenaga kerja perempuan dengan laki-laki di sektor pertanian pada tahun 2000 adalah sebesar $50,28 \%$ dari jumlah keseluruhan tenaga kerja pada sektor pertanian atau sebesar 49,60 juta perempuan. Di Indonesia pada tahun 2000 tenaga kerja perempuan yang ada berjumlah 41,41 juta, dan sebanyak 50,28 \% bekerja pada sektor pertanian. Hal ini menandakan bahwa sektor pertanian merupakan sektor yang menyerap lebih dari separoh total tenaga kerja perempuan di Indonesia. Peran perempuan dalam kegiatan ekonomi tidaklah mungkin bisa diabaikan. Apalagi di sektor-sektor tertentu yang sangat membutuhkan kesabaran, keuletan, kerajinan dan ketelitian yang lebih banyak dimiliki oleh kaum perempuan. Namun demikian tidak dapat dipungkiri bahwa keterlibatan kaum perempuan dalam kegiatan ekonomi masih diwarnai dengan adanya diskriminasi dalam beberapa hal.

Kenyataanya perempuan tidak lepas dari kegiatan ekonomi. Perempuan yang bekerja atau sebagai rumah tangga pasti akan sebagai pelaku penghasil sampah. Perempuan setiap akan menghasilkan sampah karena berhubungan dengan kegiatan di dapur. Bisa dikatakan sampah rumah tangga misalnya sisa makanan, plastik pembungkus rumhtangga kebanyakan, barang-barang tidak terpakai. Berbicara dengan sampah mungkin perempuan yang berusia produktif pada saat datang bulan, pasti akan membuang sampah bekas pembalut tersebut. Hal tersebut akan menimbulkan berbagai masalah. Oleh karena itu, perlu adanya penangan khusus, dengan adanya pemberdayaan perempuan tentang pelatihan pengelohan sampah. Pelatihan ini diharapkan akan dapat meminimalisir pembuangan sampah dengan volume besar. Mengharapkan juga terwujudnya desa bersih dan nyaman

\section{HASIL DAN PEMBAHASAN}

Desa Langko merupakan desa yang berada di wilayah Kecamatan Lingsar. Desa Langko sebagai desa yang baru berkembang, desa ini hasil pemekaran dari desa Duman. Desa Langko. Secara adminisratif desa Langko berbatasan dengan desa ; sebelah utara : Giri Madia / Hutan Tutupan, sebelah selatan : Sigerongan, sebelah timur : Karang Bayan, dan sebelah barat : Duman. Desa Langko mempunyai luas wilayah $361,72 \mathrm{Ha}$ yang terdiri dari wilayah perkebunan, persawahan, perhutanan, perkuburan, permukiman, perkantoran dan lain-lain. Wilayah desa Langko termasuk wilayah yang memiliki hutan lindung seluas $22,59 \mathrm{Ha}$.

Penduduk desa Langko berjumlah 6200 orang yang terdiri dari Jumlah laki-laki 2864 orang dan perempuan 3336 orang. Selain itu, Jumlah kepala keluarga 2259 KK. Dengan demikian Kepadatan Penduduk di desa Langko 1,65 per-km. Kondisi sosial desa Langko dapat dibagi berdasarkan beberapa aspek, yaitu agama, pendidikan, dan mata pencaharian penduduk kampung tersebut. Desa Langko, penduduknya menganut agama Islam berjumlah 2709 orang 3177 orang, yang menganut agama selain Islam berjumlah laki-laki 155 orang sedangkan perempuan 156 orang. Selain agama, kondisi social lainnya dapat dilihat dari aspek jenis pekerjaan. Pekerjaan yang banyak dilakukan oleh penduduk kampung tersebut adalah karyawan swasta, buruh, PNS, wiraswasta, petani, dan pensiunan. Sebagian besar penduduk Langko bekerja sebagai petani, karena letak kampung tersebut pertanian dan hutan lindung.

Penduduk desa Langko bermatapencaharian didominasi sebagai petani berjumlah petani laki-laki 301 orang dan perempuan 211, buruh petani laki-laki 475 orang dan perempuan 413 orang, sedangkan untuk yang belum bekerja laki-laki 674 orang dan perempuan 1633 orang. Sumber daya manusia di desa Langko bisa dikatakan masih rendah untuk kaum perempuan. Lulusan perguruan tinggi masih berjumlah 39 orang. Sedangkan, jumlah yang terbanyak untuk perempuan dengan tingkat pendidikan lulus Sekolah Dasar 1175 orang. Berdasarkan jumlah sumberdaya manusia yang dimiliki desa langko, perempuan masih belum optimal berkembang dan aktif dalam kegiatan ekonomi. Oleh karena itu, adanya kegiatan-kegiatan keterampilan sehingga perempuan di desa Langko tersebut dapatberperan dalam pembangunan desa.

Perempuan desa maupun di kota tidak lepas dari sifat konsumtif. Perempuan dalam berumah tangga pasti akan melakukan kegiatan dalam dapur untuk memasak makanan. Dalam kegiatan tersebut. pastia akan menyisakan sampah. Rumah tangga sebagai unit terkecil dari masyarakat merupakan tempat yang efektif untuk membangun kesadaran lingkungan. Melibatkan masyarakat dalam pengolahan sampah skala kecil rumah tangga, berarti tidak luput dari partispasi perempuan. Dari dalam diri perempuan memiliki peranan yang besar dalam mendidik dan membangun kesadaran memelihara lingkungan. Deklarasi Rio Jeneiro Brasil Tahun 1992 tentang lingkungan dan 
pembangunan menyatakan bahwa perempuan berperan sangat penting dalam pengelolaan lingkungan hidup dan pembangunan. Karenanya partisipasi mereka secara utuh guna perwujudan pembangunan berkesinambungan sangat penting (Hakim, 2010). Perempuan telah banyak berinteraksi dengan lingkungan dan sumberdaya alam. Banyak hasil kajian yang menunjukkan bahwa perempuan adalah manajer yang paling baik dalam penanganan lingkungan hidup.

Partipasi perempuan Langko dalam kegiatan pengolahan sampah rumah tangga ini masih dalam proses bentuk mengikuti pelatihan pengolahan sampah khusus daur ulang plasti. Pengelolahan sampah/daur ulang plastik ini merupakan program dari lembaga pendidikan Universitas Muhammadiyah Mataram. Program kegiatan disini dilaksanakan, karena hasil survey menunjukan pelatihan daur ulang yang sebelumnya masih belum terlaksana secara maksimal, tidak adanya tindak lanjut dari kegiatan tersebut. Mengingat jumlah perempuan di desa Langko yang belum bekerja masih tergolong tinggi, maka kegiatan ini bisa menambah pengetahuan para perempuan.

Karakteristik perempuan yang mengikuti kegiatan pelatihan berusia usia madya (30 tahun - 55 tahun) sebanyak 21 orang. Hal ini bisa dilihat berdasarkan jumlah penduduk yang mayoritas tergolong usia pertengahan, sehingga kemungkinan besar responden yang terpilih secara acak dengan metode simple random juga banyak yang tergolong dari usia madya. Peserta dalam kegiatan pelatihan ini keseluruhannya sudah berumah tangga. Berdasarkan hasil daftar hadir peserta. Perempuan di kampung tersebut sudah banyak yang menikah di usia muda. Rata-rata perempuan di kampung tersebut menikah setelah selesai menyelesaikan sekolahnya, sehingga di Kampung Langko jarang terdapat pemudi, disana kebanyakan adalah pemuda.

Tingkat pendidikan peserta kegiatan ini tamat Sekolah Dasar (SD), tingkat pendidikan sedang tamat Sekolah Menengah Pertama (SLTP), tamat Menengah Atas (SLTA)/MA. Berdasarkan pengamatan lapang, yang mengikuti kegiatan ini adalah ibu rumahtangga yang berusia muda rata-rata berusia 17-35 tahun. Jumlah anak yang dimiliki peserta dikategorikan menjadi empat kelompok yaitu, tidak/belum ada, 1 orang, 2 orang, dan $>3$ orang.

Kegiatan pelatihan pengolahan sampah (sampah plastik), dilaksanakan pada hari Minggu tanggal 28-29 Oktober 2017 jam 8.00 sampai jam 15.30. Kegiatan ini diikuti oleh para ibu PKK dan remaja putri dari perwakilan 7 dusun. Peserta kegiatan ini sangat antusias mengikuti pelatihan terlihat dari kedisiplin waktu, sebelum jam 8 sudah datang. Tim pelatihan dan tutor juga menyediakan alat dan bahan. Alat dan bahan yang disediakan sangat sederhana, yaitu gunting, kawat, solasi, lem, putik bunga dan bahan sampah (plastik kantong yang berwana putih, merah, hijau, kuning dll), kaleng bekas dll.

Kegiatan pelatihan pengolahan sampah (plastik) di adakan di aula kantor desa. Kami juga didampingi oleh bapak sekretaris kepala desa yang bernama bapak Rizal. Susunan kegiatan ini pertama sambutan dari Tim dan tutor dan perkenalan dengan peserta, kemudian bapak kepala desa (yang diwakili oleh sekretaris desa). Bapak sekretaris desa mengatakan "ibuibu kegitan pelatihan daur ulang ini sangat penting untuk merubah kebiasan kita untuk hidup lebih menghargai lingkungan, dengan mengikuti pelatihan ini diharapkan juga menambah pengetahuan perempuan dalam mengelolah sampah rumah tangga".

Sebelum masuk kegiatan inti, pertama tim-pelatihan menjelaskan tentang pengertian sampah, jenis-jenis sampah, dampak adanya sampah bagi kehidupan. cara pengelolaan sampah. Kemudian masuk kegiatan inti, Tutor pertama mengambil kantong-kantong plastik (kresek berwana). Kemudian kresek tersebut digunting persegi panjang sampai habis. Setelah berbentuk segi panjang, tutor mengambil beberapa persegipanjang minim 7 lembar lalu melipat-lipat seperti bentuk kipas. Selanjutnya kipas tersebut dibuka satu-persatu, sehingga akan terbentuk seperti mahkota bunga yang lagi mekar. Selain dibuat bunga juga bisa untuk asesoris bros, dipasang dijapit rambut, hiasan dinding. Satu persatu rasa ingin tahu ibu PKK, sampai ada yang berdiri karena tempatnya di belakang. Salah satu ibu celetus berbicara "kita mempratekan langsung lebih baik dari pada melihat". Dengan tidak sabarnya, ibu-ibu pada berebut bahan dan bahan. Tim sudah menyediakan bahan yang cukup. Selanjutnya, tutor membimbing dengan kesabaran mengajari ibu-ibu tersebut.

Tutor yang ke-dua membuat tempat pensil dari kaleng bekas, botol plastik. Bahan yang diperlukan selain kaleng/plastik bekas, benang wol, lem UHU/lem putih, gunting. Kaleng bekas/plastik pertama diolesi lem seluruhnya, lalu diliiti benang sampai kaleng/botol plastik tersebut tidak kelihatan. Setelah tertutup semua oleh benang,, lankah berikunya menghias agar kelihatan indah dan menarik. Bunga dari kresek juga bisa ditempel dikaleng tersebut beserta pita warna. Kaleng/botol plastik yang sudah dihias bisa 
dipakai untuk hiasan meja, atau hiasan dinding. Tidak terasa kegiatan pelatihan yang singkat ini sudah selesai. Kegiatan pelatihan berjalan lancar sesuai dengan rencana. Kegiatan ini sangat disambut baik oleh para perempuan desa Langko. Peserta pelatihan mengharapkan kehadiran Tim dan tutor tidak hanya 2 hari, bahkan bersedia mengikuti sampai bisa dan berkelanjutan. Kegiatan seperti ini memang sudah dilaksnakan sebelumnya dari instansi lain, akan tetapi para peserta ini lebih senang dari Tim dan tutor dari UMM. Mereka mengungkapkan pendapatnya "kita nyaman diajari oleh tutur yang sabar, pelan-pelan sehingga kami tidak sungkan, takut untuk bertanya. Pelatihan yang dulu tutornya galak jadi kita takut bertanya".

\section{SIMPULAN DAN SARAN}

\section{Simpulan}

1. Peserta pelatihan pengolahan sampah (plstik) sangat antusias dan termotivasi untuk memanfaatkan sampah rumah tangga, agar lebih bernilai.

2. Kegiatan pelatihan pengolahan samapah plastik dapat mengurangi volume sampah yang dihasilkan rumah tangga, sehingga akan terwujudnya pedesaan yang nyaman bebas dari sampah. Desa Langko yang mandiri dan kreatif.

\section{Saran}

1. Kegiatan pengolahan sampah rumah tangga (sampah plastik) sebainya dilaksanakan seminggu sekali dan berlanjut secara kontinu.

2. Kegiatan pengolahan sampah/plastik tidak hanya membuat bunga, acesoris dll tetapi mengharapkan kreatifitas yang lain.

3. Pemerintah desa sebaiknya respon terhadap kegiatan pengolahan sampah/plastik, sehingga skill perempuan desa Langko semakin bertambah

\section{DAFTAR RUJUKAN}

Chaesfa, Yulanda \& Pandjaitan, Nurmala K. 2013. Persepsi Perempuan Terhadap Lingkungan Hidup Dan Partisipasinya Dalam Pengelolaan Sampah Rumahtangga. Sodality : Jurnal Sosiologi Pedesaan | Agustus 2013, hlm: 165-18. ISSN 2302-7517 Vol 1 No.02

Hakim H. 2010. Alasan kenapa perempuan harus menjadi subjek dalam mengelola sampah. [internet]. diunduh 6 Juli 2012]. Diunduh dari: http://green. kompasiana.com/limbah/2010/11/07/alas an-

Profil desa Langko. Potensi desa langko dalam tahun 2013 dan 2014.
Profil desa Langko. Tingkat perkembangan desa Langko dalam 2013 dan 2014.

UU. Undang-undang No. 18 Tahun 2008 tentang Pengelolaan Sampah.

UU. Undang-Undang No. 32 Tahun 2009 tentang Perlindungan dan Pengelolaan Lingkungan Hidup 